\title{
イングランド南東部ウィールド地方におけるオークの自然誌
}

\section{若生 達 夫*}

オーク (oak) は，その自然林からは建物や船の構造 材, 家具ほかの内装材を, 萠芽林からは良質の薪炭材・ 皮なめし液用の樹皮を供給し，森や木材の王様と呼ば れた。英語の “oak”は，邦訳ではしばしば「カシ(樫)」 とされるが, Quercus 属を表すので，ナラ・カシ類が適 切である。ここでは日本語でも広く用いられている 「オーク」と記す。

本論は筆者が 10 年間に繰り返し訪ねたイングラン ド南東部のウィールド地方において観察したり，資料 収集したことにもとづいて，いわば「オークの自然誌」 を述べてみたい。その内容は，(1) オークのイングラ ンド在来種は 2 種であり，それらの生育地と土地性状 との間 (立地) に密接な関係があること，(2) 萠芽林 が現在の土地景観にも反映されていること，(3) オー クの利用の歴史，の3つである。

\section{I. ウィールドの自然}

\section{1. ウィールド背斜の地区の地形}

ノースダウンズ (North Downs), サウスダウンズ (South Downs）のチョーク（白巠）の丘とその間の低 地は, 近代地質学の初めから注目され, ウィールド背 斜と名づけられた(第 1 図)。南の丘は19 世紀まで Sovth Downs と書かれているが，17 世紀のある時期 まではvは $\mathrm{u}$ を兼ねていて，地名などは長く変わらな かった（vの2 連字は，今でも，ダブル・ユーと読む。 ロンドン市内セントポール寺院の彫刻にSovth の表 記例を見た)。

ウィールド背斜に現れる地層は,すべて白巠紀層(深 所にジュラ紀層)であり，背斜部が侵食低下を受けて， 中小規模でみれば，ホッグバック (Hog's Back一ブタ の背）という風な構造地形が生じ，チョークの丘を貫 く川も地質の弱線に沿っていると言われる。

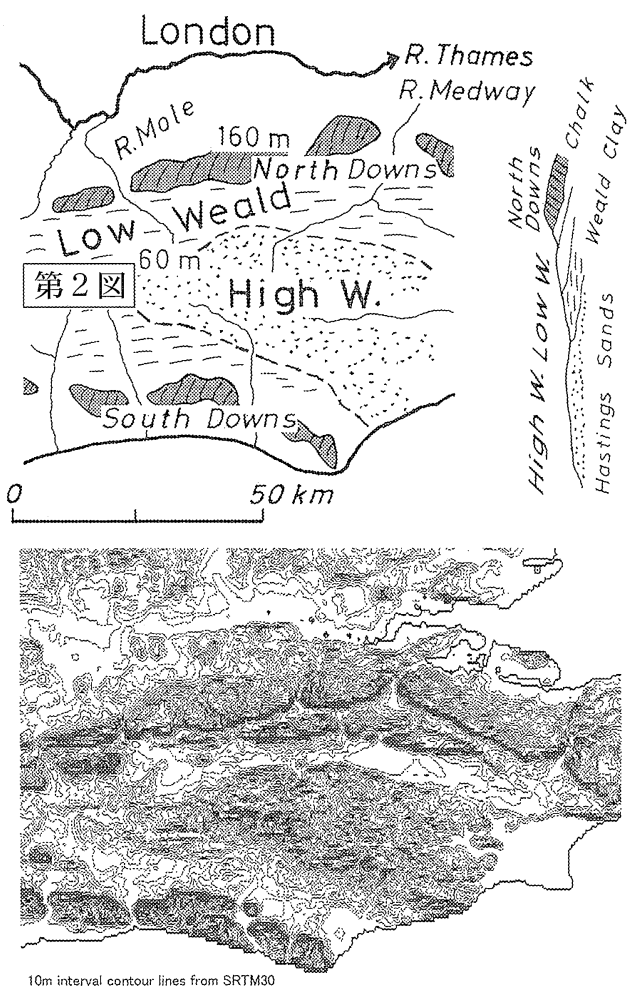

第 1 図 チョークの丘とウィールド低地

\section{2. ウィールド低地}

低地は，南東部のハイウィールド (High Weald) と 北西部のロウウィールド (Low Weald) とに分けられ る(第 1 図)。前者は, 砂岩を主体とするへイスティン グ砂岩層 (Hastings Sands) が丸味ある地形を呈し，雨 水の滲透が良く，小河川の源流部となっている。古く から耕地がひらかれ, 数十年前まではホップ栽培が,今 ではブドウを含む果樹が作られている。同砂岩層は鉄

* 宮城教育大学名誉教授, 2006 年 12 月 11 日没 
鉱石を含み, $\mathrm{AD} 1 \sim 4$ 世紀頃のローマ軍団時代から製 鉄が行われていた。

後者のロウウィールドはシルト岩のウィールド泥岩 層 (Weald Clay) で構成され，透水性は悪く，林地と して長く残った所，正に，古い英語Wald (森林) に由 来するWeald という名の所である。一般耕地には向か ないが, 後述のようにイングリッシュオークには適し ている。

このウィールド泥岩層の部分は, 層序上はへィス ティング砂岩層の上位にあるが, 滲透性の徳い所は (一 部の硬岩部分をのぞいて）表流水により侵食が進み易 く, 滲透性の良い部分よりも低くなる。ウィールド泥 岩層の部分では, 起伏のはっきりしない, のっぺりし た地表形を呈する。

\section{3. 水系}

低地の北側に限って述べる。北東側に流れるメド ウェイ川 (Medway) は, 水量が豊富で，テムズ川河 口付近のエスチュアリイに入る。中流部まで舟運が行 われていた。エスチュアリイ周辺には 18 世紀の海軍造 船所とチョークの丘の石灰を利用するセメント工場が あり,少なくとも20 世紀中頃まではチョークの最大消 費地であった。

北西側に排水するモール (Mole) 川は，ウィールド 泥岩層地域を流域とし, 雨の後には瞬時に出水し, す ぐにピークがすぎる川である。そのため水運はおろか, 水車の設置にも適さない。細かい支流の密度が高い。こ れらの小川はbrook と言われ，固有名がついていて， Taxner's brook という皮なめしと関連していたらし いものもある。

イングランドには, 小川を言う言葉が他にもあった。 fleet, bourn, boarne であるが，現在では，ロンドンの Fleet 川，West bourne 川などの地名としてしか残つ ていない。

\section{4. 道路}

ロウウィールドは，森林のほか，小川が多く，重粘 な表土が交通の障害になっていた。馬蹄形状にひろが るため,とり囲まれるハイウィールドも不利であった。 このような不利を克服するには水路の利用があるが, ここでは，それにも恵まれていない。従って，広域を 結ぶ交通路としては避けられ, 巡礼者の道はチョーク の丘にあった。現在のノースダウンズ街道 (North Downs Way) は，それと大体同じコース ( $1 / 5$ 万地形 図にあり)をたどることができる。

\section{II. ウィールドのオーク}

\section{1. オークの在来 2 種}

イングランドの在来種は，ヨーロッパナラ (English Oak (Quercus robur)) とフユナラ (Sessile Oak ( $Q$. petraea))である。この 2 種は, 北欧を除くヨーロッパ 大陸に広く分布する。したがって，国や地域でそれぞ れの名称がつけられており, 学名も地方で異なる。和 名としては，それぞれヨーロッパナラ，フユナラが当 てられているが, 前者にコモンオーク (Common Oak) や後者にセシルオークの名称も用いられる。Sessile は 果実（ドングリ）の柄，つまり果柄の長いヨーロッパ ナラと比較して,フユナラが無柄か短いことに由来し, 両種を容易に区別する特徵になっている。以下，ヨー ロッパナラをイングリッシュオークとし，フユナラを セシルオークと表記する。イギリスでの年輪年代学で 最も古くまでたどれたのはオークにより 7,000 年前ま でである。

なお 1735 年に大陸から導入されたターキーオーク (Turkey Oak, Quercus cerris，和名不明）は姿が良く 成長が早いので，公園などに向くが，木材資源として の価値はないという。

イングリッシュオークは, 低地の広い範囲に分布し, 土性・土湿に対して耐性が強い。これに対し，セシル オークは北部・西部にも広がり, 南では丘陵などの軽 い土を好む。湿地は苦手である。

両者は，接近する所では交雑しており，それは，お そらく先史時代に始っていると見られている。

そのような中にあって，例外の所がある。イングラ ンド北部・西部ではイングリッシュオークの侵入がな く, セシルオークのみが分布している。もう一つの例 外は, ロウウィールドであり,ここは, イングリッシュ オークの純血を保ってきた。セシルオークは南まで分 布するのだが，チョークの丘や八イウィールドに限ら れ，湿地带のロウウィールドには侵入しなかった。

両種ともに樹高は $40 \mathrm{~m}$ くいになる。樹形は, 個体 により，また，周りの条件により様々になるが，一般 に，イングリッシュオークは地上のあまり高くない所 で大枝を出し，セシルオークはより高い所で中枝を出 す。従って，両者の樹冠の形も異なる。公園など開け た所などでは,イングリッシュオークが愛でられるが, 街路や宅地では，よりすらりとしたセシルオーク（お よびターキーオーク）が好まれる。 


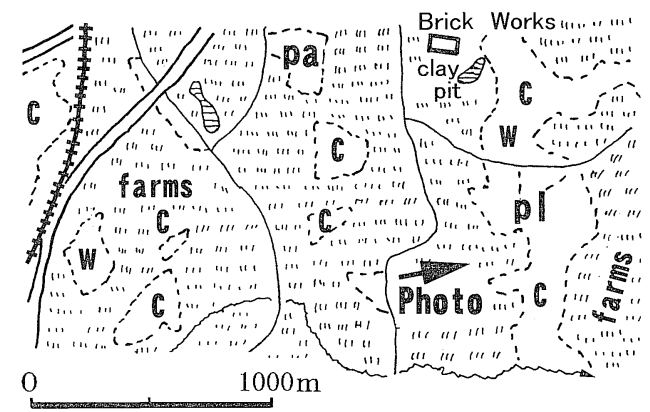

第 2 図 ウィールド低地西部カペル (Capel) 付近の農 林地名 (field name) の一例（すべてに固有名 がついている)

c : copse 萠芽林 w: wood 林

$\mathrm{pl}: 19$ 世紀植林地 plantation

pa：park 公園 farms：牧場

\section{2. グロオウン・オークとチャペル}

グロオウン・オーク (grown oak) とは，木材の王 様オークの中の「湾曲した幹や幹と大枝への分岐部と を，まとめていう原木呼称」である。家屋や船の骨組 みに利用され, 非常に貴重とされる部材 (縦・横材の つなぎ目の三角材に相当)である。樹形の特徴から,グ ロオウン・オークは，イングリッシュオークからより 多く採られたと考えられる。

ウィールドには，14・15 世紀の木造教会が数ヶ所 残っている。みな小さい。グロオウン・オークを使っ た見事な内部構造が，地元の人によって写真入りで紹 介されている。今となってはぜいたくとさえ言光る。石 材を買い集めることはできず，人口も少なかったから だ，と紹介されているが，グロオウン・オークと直材 を多くとれるすらりとした木の価格に違いがあったの であろうか。

小さな教会チャペル（chapel）は，人口が疎らな所 に建てられ，遠くにあるチャーチ (Church) の支所的 役割で置かれたものもある。チャーチには年何回か行 くだけである。

第 2 図は Capel(カペル) という所で，チャペルのな まり。鉄道駅は，レンガ建てだが今は，イングランド 全体にみられるように無人である。こんな田舎は，停 車する列車も少なく不便である。

Capel のチャペルの隣にパブ(Public House)があっ た。ビールを昼間から飲める。Public House の言葉ど おり，老若男女がおしゃべりにくるコミュ二ティ・セ ンターと言ってよい。ほとんどの集落にあり, $1 / 5$ 万地
形図にも表示されている。筆者は，この 10 年の訪英で 90 ケ所くらいを（要するに，毎日）利用した。都会の パブは居酒屋のようで面白くない。

ここのパブは，その名も“The Grown”。ロンドンか ら着いて先ず入り，その後，野外を歩く。雷雨にうた れて, また入る。この時には, レンガ工場の人がレン ガのサンプルを持ってきて施工業者らしい人に渡して いた。パブは，仕事の打合せなどにも使われる。日本 にもレンガはあるかと聞かれた。実は，近代化の時の 日本は，レンガもイギリスから輸入した。

この付近には,古くから中小のレンガ工場があった。 カペル鉄道駅には,レンガ工場からの引込線もあった。 今は, 粘土採掘場 (clay pit), または, 跡地の池に, そ の名残をとどめている。

\section{3. 製鉄用製炭のための萠芽林}

オークの萠芽林は, 垣根などの用材や薪炭，皮なめ し用樹皮のために育てられた。さらにウィールドは， 16・17 世紀，イングランドの鉄の主生産地であった。

1) $\mathrm{AD} 1 \sim 4$ 世紀のローマ軍は, Hastings Sands の 鉱石を使って製鉄した

錬鉄 (wrought iron) は鉄鉱と木炭を粘土で覆い，高 熱で酸化鉄の炭素を $\mathrm{CO}_{2}$ として逃がし，その後，鍛冶 屋風にたたいたりして精製する。展性があり，たたい て接合 welding もできる。

この技術は世界各地にあり，鉄の硬さをきめる炭素 含量が少ない。それに，錆びにくいなどの特徴があり， 今でも入手したがる技能者がいる。

その特徵は，原鉱を溶かしていないことと，木炭を 多量には使わないことである。wrought とは，後世の 技術者が，その特性に対して与えた敬称で，「極めて精 巧に作られた」の意である。

2）ウィールドは $16 ・ 17$ 世紀イングランドの鉄の主 生産地になった

大陸から高炉 (真立炉) が導入された。鉱石と木炭 を炉に入れ，ふいごで吹風して溶けた鉄を下に流し出 す。すなわち溶鉱炉である。受ける所は砂床で，幹線 と何本かの支線を掘り込んだ様子が，母親の乳房にす いつく子ぶたに似ているので，pig iron（銑鉄）と呼ば れる。砂床の所に鋳形 cast を用意してお枋げ，大砲で も民生品でも多量に作れる。cast iron (鋳鉄)である。

溶鉱の送風・鍛造用ハンマーの動力は, 共に, 水車 によった。川がなければできない。ウィールド製鉄と 言っても, 大部分は八イウィールドにあり,ロウウィー 


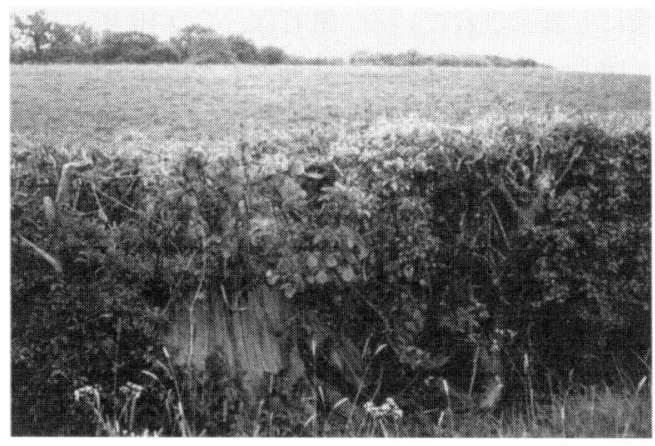

写真 1 . 農林地の一例 (位置は第 2 図参照) 奥は Green's copse, 中央は Broomell's Farm, 手前は hedge (生垣, 古切株を含む)

ルドでは1ヶ所しか工場が確認されていない。後者は, 木炭供給地だったのであろう。

3）バーミンガム西方で，1708 年，初代ダービーは 使われていなかった木炭高炉を買い, コークス 製鉄を始めた

背後の丘に貯水池をつくり, 水車の安定的運転を確 保した。原鉱は夾炭層中のもので一石二鳥。数で稼げ る鍋を多く作った。ここで作られた鯨油採取用の大鍋 がホノルルに保存展示されているという。

精鍊法の技術改良が行われて炭素量の様々の鋼鉄 (steel）が作られるようになった。

\section{4. 萠芽更新林など農林地名}

第 2 図はカペル付近の例であるが，それぞれの区画 ごとの固有名詞 (field name) がつけられている（写真 1)。farm の区画の図示は省略し一括した。牛(ごく一 部が馬）の飼育にあてられている。Wood と名のつい ている所はうっそうとしており, 萠芽更新の林地 (coppice, 短縮形 copse）は雑木林という感じである。

木炭生産は，広くは19 世紀まで続けられたし，暖炉 の趣味だろうか，今も，薪を大量に積んでいる家があ る。Copse などの区画は，昔から縮小・消滅が大きく 行われたとは思われない。

農耕地の区画は，木立列と生垣の双方があり，混用 している場所もある。その解釈に興味を持っている人 もいるが，簡単ではないらしい。従って，写真 1 は生 垣の中に古株があるから，木立から生垣へ変った例と 考えられる。

イギリス南東部门ィールドのオーク林は, 歴史的に 木材，製鉄やレンガ製造のための薪炭，革製造などの 産業を支えてきたが，萠芽更新の林地や土地利用景観 は，いまもなお地形地質水文の自然環境を強く反映し ている。

\section{付 記}

投稿中断していた 2003. 11.30 稿を阿子島 功（山形大） と三浦 修(東北福祉大)が一部改訂して投稿したものであ る。

(2008 年 1 月 8 日 受付)

\title{
The Natural History of Oak in Low Weald, Southeast England
}

\author{
Tatsuo WAKO*
}

* Professor Emeritus at the Miyagi University of Education, deceased on 11 Dec., 2006 